\title{
Meta
}

Journal des traducteurs

Translators' Journal

\section{Cultural Translation, Long-form Journalism, and Readers' Responses to the Muslim Veil}

\section{Kyle Conway}

Volume 57, numéro 4, décembre 2012

Journalisme et traduction

Journalism and Translation

URI : https://id.erudit.org/iderudit/1021229ar

DOI : https://doi.org/10.7202/1021229ar

Aller au sommaire du numéro

Éditeur(s)

Les Presses de l’Université de Montréal

ISSN

0026-0452 (imprimé)

1492-1421 (numérique)

Découvrir la revue

Citer cet article

Conway, K. (2012). Cultural Translation, Long-form Journalism, and Readers' Responses to the Muslim Veil. Meta, 57(4), 997-1012.

https://doi.org/10.7202/1021229ar
Résumé de l'article

Le présent article examine la traduction des nouvelles comme forme de traduction culturelle, ainsi que la réception des lecteurs à ce mode de journalisme. En particulier, il considère la série Derrière le voile... des femmes, diffusée par Radio-Canada.ca en mai 2010, à travers le prisme de la discussion de la relation $J e$-Tu de Hans-Georg Gadamer. Il considère d'abord les reportages eux-mêmes, puis les commentaires laissés par des lecteurs. La série explique les raisons pour lesquelles certaines musulmanes choisissent de porter un niqab (voile), mais les commentaires révèlent que les lecteurs refusent en grande partie de croire que ce choix soit libre. En revanche, les commentaires révèlent aussi que les lecteurs sont prêts à participer à une espèce de conversation, ce qui indique un bénéfice potentiel du journalisme interprétatif.
Ce document est protégé par la loi sur le droit d'auteur. L'utilisation des services d'Érudit (y compris la reproduction) est assujettie à sa politique d'utilisation que vous pouvez consulter en ligne.

https://apropos.erudit.org/fr/usagers/politique-dutilisation/ 


\title{
Cultural Translation, Long-form Journalism, and Readers' Responses to the Muslim Veil
}

\author{
KYLE CONWAY \\ University of North Dakota, Grand Forks, United States \\ conway.kyle@gmail.com
}

\begin{abstract}
RÉSUMÉ
Le présent article examine la traduction des nouvelles comme forme de traduction culturelle, ainsi que la réception des lecteurs à ce mode de journalisme. En particulier, il considère la série Derrière le voile... des femmes, diffusée par Radio-Canada.ca en mai 2010, à travers le prisme de la discussion de la relation Je-Tu de Hans-Georg Gadamer. Il considère d'abord les reportages eux-mêmes, puis les commentaires laissés par des lecteurs. La série explique les raisons pour lesquelles certaines musulmanes choisissent de porter un niqab (voile), mais les commentaires révèlent que les lecteurs refusent en grande partie de croire que ce choix soit libre. En revanche, les commentaires révèlent aussi que les lecteurs sont prêts à participer à une espèce de conversation, ce qui indique un bénéfice potentiel du journalisme interprétatif.
\end{abstract}

\begin{abstract}
This article examines, first, news translation as a form of cultural translation, and, second, readers' responses to this mode of journalism. In particular, it examines the series Derrière le voile... des femmes, published in May 2010 by Radio-Canada.ca, through the lens of Hans-Georg Gadamer's discussion of the I-Thou relationship, looking first at the stories in the series and then at readers' comments. This series explained why some Muslim women chose to wear a niqab or veil, but the comments revealed that readers were largely unwilling to see the choice as one made freely. However, the comments also revealed that readers were willing to engage in conversation, pointing to one potential value of long-form interpretive journalism.
\end{abstract}

\section{MOTS-CLÉS/KEYWORDS}

niqab/voile musulman, Québec, journalisme interprétatif, traduction culturelle, études de l'auditoire

niqab/Muslim veil, Quebec, long-form journalism, cultural translation, audience/reception studies

\section{Introduction: Readers and long-form interpretive journalism}

What role can news media play in helping readers, listeners, and viewers understand people they perceive as Other? Conversely, what role have they played in hindering such understanding? These questions are pressing in the contemporary global context where geopolitics and economics cast a wide range of Others in an increasingly menacing light. Examples abound. One of the most prominent - and, not coincidentally, my interest here - is that of Western news accounts of Islam. As Said (1997) demonstrates, Western media have produced an image of "Islam" as a mysterious, hostile Other, and that image has served to justify the West's military and economic intervention in a wide range of Muslim countries. One challenge in answering these questions, however, is the fact that neither entity is as homogeneous as labels such as 
"the West" or "Islam" suggest. Totalizing accounts obscure the internal differences within each group, a fact that signals the need for case studies that address the nuances of relationships between specific groups or communities. This article presents one such case study.

In the past decade, but especially since 2006, the Canadian province of Quebec has dealt with a series of controversies related to reasonable accommodations for religious minorities, many of them related to the public display of religious symbols. One focal point has been the niqab or face veil worn by a small group of Muslim women. In March 2010, Quebec's justice minister, Kathleen Weil, introduced Bill 94 in the provincial legislature, called An Act to Establish Guidelines Governing Accommodation Requests Within the Administration and Certain Institutions. ${ }^{1}$ The bill would effectively limit women's choice to wear a niqab in specific circumstances. Shortly thereafter, in May 2010, Radio-Canada.ca, the French-language website of the Canadian Broadcasting Corporation, published a series of seven stories by AnneMarie Lecomte, collectively titled Derrière le voile... des femmes [Women behind the veil] to explain to readers why certain women chose to wear a niqab. ${ }^{2}$ My purpose here is to examine this series and the responses it generated. Specifically, I read the stories and the comments left by readers through the lens of Hans-Georg Gadamer's discussion of the I-Thou relationship to evaluate the degree to which the journalist's fundamentally hermeneutic act had its desired effect, namely to help readers see the niqab from a culturally foreign perspective.

I am building here on the growing literature on news translation, and I am addressing two questions that have received only limited attention. The first question relates to modes of journalistic translation. Although many scholars have addressed the role of translation in expository journalism, examining aspects such as framing (Gambier 2006) and word choice (Sorby 2006), few have considered news translation as a form of cultural translation, where journalists try to explain to one group how another sees the world. In what ways do long-form interpretive stories show evidence of this process? The second question relates to readers' modes of consumption. Although many scholars have argued that journalists adopt an acculturating, audience-oriented approach to news translation, treating it much like a form of localization (Pym 2004: 4; see also Bassnett 2005; Gambier 2006), few have examined audiences' actual responses (Conway and Vaskivska 2010). How do they interact with the stories they read? Specifically, do the comments they leave on Internet discussion boards indicate whether the stories change their perception of the people they are reading about? To address these questions, I begin with a description of the events leading up to Radio-Canada.ca's publication of the Derrière le voile series (section 2), paying special attention to Quebec's reasonable accommodation crisis and Bill 94. I follow this with a description of Gadamer's account of the I-Thou relationship (section 3), which provides the framework to examine the Derrière le voile series as a form of cultural translation (sections 4-4.2). I then examine readers' modes of consumption (section 5) by describing what their comments reveal about how they interacted with the series and with comments left by other readers, looking first at the form of their comments (section 5.1) and then at the content (sections 5.2-5.3), again through the lens provided by Gadamer. I conclude by considering what this case study reveals about the potential of news media to help readers, listeners, and viewers understand people they perceive as Other (section 6). The answers to these questions about modes 
of news translation and its consumption, at least in this case study, reveal that journalistic cultural translation is a complex and internally contradictory process that can encourage conversation, but not necessarily empathy or increased understanding, between groups that perceive each other as foreign.

\section{Historical context}

In many ways, Quebec's reasonable accommodation crisis has resulted from Quebecers' perception of the province's recent history, in particular the Quiet Revolution of 1960s (Conway 2012b). From the era of French colonization in the sixteenth and seventeenth centuries up through the 1950s, the Catholic Church exercised considerable control over Quebec society. The 1960s marked the beginning of Quebec's modern nationalist movement, which was led by people who wanted to create the conditions necessary for the survival of a French-speaking minority in a predominantly Englishspeaking country. To this end, Quebec's new class of leaders began to exercise more control over the province's educational system and other social institutions, such as hospitals and trade unions. These institutions had previously fallen under the influence of the Church, which lost the clout it once had. In this way, Quebec's modern nationalist project was accompanied by the province's secularization.

Quebecers, especially those of French-Canadian origins, continue to consider secularism an important - and hard-won - legacy of the Quiet Revolution. Many also perceive a threat in the rapid growth of Quebec's Muslim community in the last two decades, especially when immigrants maintain outward expressions of their faith. As pollster Michael Adams has found:

Canadians at large, particularly Quebecers, were less certain [than Muslims themselves] about Muslims' willingness to integrate and placed great stock in symbolic adaptations, such as the abandonment of religious clothing. Hijabs [headscarves] and niqabs [face veils] were seen by many secular Canadians, particularly Quebecers from Catholic backgrounds, as symbols of patriarchy and a form of religiosity that Quebec as a society largely abandoned only a few decades ago. (Adams 2009: 23)

It is important to note that the growth of the Muslim community in Canada (and Quebec more narrowly) is a relatively recent phenomenon. The 1931 census, for instance, found that only about 3 percent of Canadians identified as neither Christian nor Jewish, a rate that remained relatively steady in the 1941 and 1951 censuses, before rising to about 4 percent in 1961 (Kalbach 1970: 68). Although the census information does not break the "other" group down into its constituent parts, it is possible to get a sense indirectly of the number of Muslims living in Canada. For instance, by 1967, according to a report by the Canadian Citizenship Branch of the Department of the Secretary of State, the number of people from the Middle East (broadly conceived) stood at about 35,000, although the report does not indicate how many were Muslim. ${ }^{3}$ In the past two decades, however, Canada's Muslim community has grown dramatically, with immigrants in English-speaking Canada coming largely from India, Pakistan, Lebanon, Syria, Iraq, and Iran, and immigrants in French-speaking Quebec coming largely from the francophone Maghreb region of North Africa (McAndrew 2010). In 2001, Muslims accounted for about 2 percent of the country's population, a rate that was predicted to rise to more than 4 percent by 2017. This growth has been especially visible in Canada's major cities. In 2001, more than 3 percent of people in 
Montreal were Muslim, predicted to rise to about 6 percent by 2017 (Dib 2006: 40-41). The visibility of certain expressions of religious belief, in conjunction with the community's rate of growth, has magnified many Quebecers' perception of risk to their society (Adams 2009).

The concern about the secular legacy of the Quiet Revolution was at the heart of the controversies about reasonable accommodations that reached a high point in 2006 and 2007. These controversies prompted Premier Jean Charest in 2007 to convene the Consultation Commission on Accommodation Practices Related to Cultural Differences, which was co-chaired by sociologist Gérard Bouchard and philosopher Charles Taylor. ${ }^{4}$ The commission wrote in its report that the practice of reasonable accommodations began in the realm of labor jurisprudence in the 1980s, where it served as a means to overcome de facto discrimination faced by people with physical disabilities: employers would make changes to working conditions so that people could accomplish the tasks of their job, so long as those changes did not impose an undue burden on the employer. Hence, they would accommodate workers, so long as the accommodations were reasonable. By the early 2000s a number of prominent cases involving a range of religious minority groups, including Sikhs, Muslims, and Orthodox Jews, began to draw attention to the religious reasons for which accommodations might be granted. By 2006, according to the commission's report:

Debate was no longer confined to the question of minority religious practices but now encompassed the much broader question of the integration of immigrants and minorities. A phenomenon that had begun to emerge during the preceding period now became fully apparent: part of the population reacted to accommodation requests as though it felt wronged by what it perceived to be "privileges." (Bouchard and Taylor 2008: 15)

The Bouchard-Taylor commission, however, did not succeed in putting an end to the controversies, and in March 2010, Justice Minister Kathleen Weil introduced Bill 94 in the National Assembly (see note 1). The bill would require all people requesting services from the government, as well as the governmental representatives fulfilling those requests, to interact with their face uncovered. Although it does not mention Islam explicitly, it would have a disproportionate effect on Muslim women wearing a niqab, as many observers point out. ${ }^{5}$

According to a poll taken shortly after the bill's introduction, support was as high as 95 percent within Quebec. ${ }^{6}$ However, public testimony in the National Assembly suggested that Quebecers' support for Bill 94 was more complex than polls made it appear. More than half of those testifying supported the bill because, in their view, it would uphold the ideals of the Quiet Revolution, in particular its legacy of secularism. An important number of witnesses supported it for other reasons, however, related less to values and more to pragmatic questions of legal clarity. Still others opposed the bill because they saw it as a form of discrimination against a minority religious group (Conway 2012b).

It was in this context that Radio-Canada.ca published the Derrière le voile series in May 2010. The first story, Un vêtement controversé, provided an overview of the series, while the following two stories described a feminist Muslim woman who wore a niqab, in Je suis une féministe musulmane en niqab!, and a woman who wore a niqab before deciding to give it up, in the story Adopter le niqab, puis le laisser. The fourth story, Pour une charte de la laïcité, described the vice-doyenne [associate dean] of 
continuing education at the Université de Montréal, who advocated an official charter on secularism. The fifth story, Protéger les marginaux, featured the spokesperson of Présence musulmane Montréal, an advocacy group working on behalf of Montreal's Muslim community. The sixth story, Un processus historique, consisted of an interview with two religious studies professors from the Universite de Sherbrooke. The concluding story, Plaidoyer pour l'intégration, described the director of the Centre d'appui aux communautés immigrantes, which was at the center of one of the controversies prompting Bill 94.

How can we understand these stories as acts of cultural translation, especially in light of the complicated nature of public opinion about the bill? It is here that Gadamer's account of the I-Thou relationship proves useful.

\section{Gadamer's account of the I-Thou relationship}

The consultation commission addressed the "broader question of the integration of immigrants and minorities" (Bouchard and Taylor 2008: 15; see note 4) by putting forward eleven proposals related to Quebec's policy of interculturalism. As Bouchard and Taylor explain, "interculturalism as an integration policy has never been fully, officially defined by the Québec government” (Bouchard and Taylor 2008: 39), but the approach it encourages has been relatively consistent, namely to promote the integration of immigrants in a manner that is respectful of their cultures of origin while still preserving francophone Quebec society. Bouchard and Taylor intended their proposals to provide a more precise definition. The second and third are useful for framing consideration of the Derrière le voile series:

2. In a spirit of reciprocity, interculturalism strongly emphasizes interaction, in particular intercommunity action, with a view to overcoming stereotypes and defusing fear or rejection of the Other, taking advantage of the enrichment that stems from diversity, and benefiting from social cohesion.

3. Members of the majority ethnocultural group, i.e. Quebecers of French-Canadian origin, like the members of ethnocultural minorities, accept that their culture will be transformed sooner or later through interaction. (Bouchard and Taylor 2008: 40-41)

Such interaction and transformation are possible, however, only if people approach each other with a sense of openness, as Taylor argues in his more overtly philosophical treatise, The Politics of Recognition (1994), in which Quebec serves as a prominent case study. People who see the Other as an object to be known, rather than as a subject endowed with agency, are unlikely to be persuaded to "accept that their culture will be transformed" (Taylor 1994: 40). To make this argument, Taylor draws on Hans-Georg Gadamer's Truth and Method (1960/2003[1989]), in which Gadamer discusses the I-Thou (Ich-Du) relationship. He describes three different orientations speakers adopt toward the Other, or in his terms, three ways of "experiencing the Thou." In the first way, the Other - that is, the Thou - is an object to be known:

There is a kind of experience of the Thou that tries to discover typical behavior in one's fellowmen and can make predictions about others on the basis of experience. [...] We can understand the other person in the same way that we understand any typical event in our experiential field - i.e. he is predictable. (Gadamer 1960/2003[1989]: 358) 
In the second way, the Other is a subject, but one whose agency the speaker effectively denies: "One claims to know the other's claim from his point of view and even to understand the other better than the other understands himself" (Gadamer 1960/2003[1989]: 359). In the third way, the Other is a subject whose actions and thoughts the speaker does not (indeed cannot) claim to know in advance:

Here is where openness belongs. But ultimately this openness does not exist for the person who speaks; rather anyone who listens is fundamentally open. [...] Openness to the other [...] involves recognizing that I myself must accept some things that are against me, even though no one else forces me to do so. (Gadamer 1960/2003[1989]: 361)

We can see evidence of all three orientations in Quebecers' reactions to Bill 94. The first orientation was observable, for instance, in the numerous a priori statements made by witnesses addressing the National Assembly about the nature of the niqab and, by extension, the reason women wear it. For example, the Association des retraitées et retraités de l'éducation et des autres services publics du Québec (2010), a labor group, declared in its written brief that the imposition of the niqab was "clearly discriminatory" and a threat to the equality between men and women. ${ }^{7}$ The second orientation was observable in a related set of statements made by witnesses who at first expressed openness to the idea that women wearing a niqab chose to do so freely but then concluded that they knew better than these women what wearing a niqab meant. The Confédération des syndicats nationaux (2010), another labor group, submitted a brief along these lines, at first allowing that women wearing a niqab generally did so for reasons of religious conviction, but then insisting that in the context of Quebec and its historical struggle for secular state institutions, such a choice could be seen only as a symbol of women's submission to men. ${ }^{8}$ Finally, the third orientation was observable in statements made by witnesses expressing a desire to hear from the women wearing a niqab themsleves. One of the clearest statements along these lines came from the Fédération des Canadiens Musulmans (2010), a group working to protect Muslims' rights in Canada, which argued that it was inappropriate for Western feminists to impose their notions of equality on all women and that people wishing to understand why women wore a veil should ask those women themselves. ${ }^{9}$ Religious groups were not the only ones to demonstrate this type of orientation; groups operating from an "anti-colonial, anti-racist" feminist perspective made similar arguments (for example, Simone de Beauvoir Institute 2010). ${ }^{10}$

How do these three orientations help us understand the Derriere le voile series as a form of journalistic cultural translation? And how can they help us characterize readers' responses to the series, as those responses were registered in the comment section accompanying the series? It is to those questions that I turn my attention now.

\section{Derrière le voile as cultural translation}

In contrast to much of the extant literature on news translation, which has focused on the structural factors shaping the circulation of news stories across linguistic lines (e.g. Fujii 1988) or on journalists' institutional roles in collecting and disseminating stories about foreign cultures (e.g. van Doorslaer 2010), I am interested in how news translation functions as a form of cultural translation. I am drawing here on notions 
of cultural translation advanced by anthropologists such as Talal Asad (1986) and Shirley Ann Jordan (2002), who treat it as a form of description meant to explain to one group of people how another group interprets an object or event. Cultural translation in this sense is a fundamentally hermeneutic act. As such, openness to the Other is a necessary condition: journalists who adopt the first or second orientations described above risk imposing their preconceived notions on the people they attempt to describe, missing the very point of their act of interpretation. ${ }^{11}$

\subsection{Derrière le voile and its interpretive impulse}

The interpretive impulse behind the Derrière le voile series derived from multiple sources. In a general sense, the Canadian Broadcasting Corporation has the mandate to "reflect the multicultural and multiracial nature of Canada." 12 In a more immediate sense, Anne-Marie Lecomte wrote in her introductory story about Naïma Atef Ahmed, an Egyptian woman and pharmacist by training, who was expelled from a French-language course run by the Centre d'appui aux communautés immigrantes when she refused to remove her niqab. There was a gulf of incomprehension, according to Lecomte, between Ahmed and the people who watched her explain herself on the cable news network RDI after her expulsion, a gulf that the series was meant to address. The debate was broader than the niqab, she wrote, and the series could not provide definitive answers. Instead, it could contribute to an ongoing, unfinished conversation (Un vêtement controversé).

The immediate impulse, then, demonstrated the third orientation toward the Other: Lecomte was providing a space for women whose experience was different from her own to explain how they interpreted the niqab. The structure of the series supports this observation, too: the interpretive value of the stories Je suis une féministe musulmane en niqab! and Adopter le niqab, puis le laisser results largely from Lecomte's decision to let her interviewees speak at length about their lives. Dayna Ahmed, in Je suis une féministe musulmane, even explains how much she has wanted the opportunity to explain herself and thanks Lecomte for the interview.

\subsection{Contradictions within the interpretive mode}

The series demonstrated, however, that interpretive modes of journalism involve more than mere explanation and can be internally contradictory. Although Lecomte demonstrated a certain openness toward the Other, the orientations of the people in her stories toward each other varied. The person who most clearly demonstrated the third orientation toward women wearing a niqab was Leila Bdeir, spokesperson for Présence musulmane Montréal. Indeed, her role as advocate on behalf of Muslims would have made no sense without an openness to them as acting subjects. She (and Lecomte) made this point by explaining that treating Muslims as if they were the Other has repercussions on actual people. Questions of identity are complex and have no easy answers, Bdeir added, and what is important is to create an open space for conversation (Protéger les marginaux).

Other people featured in the series adopted closed orientations toward women wearing a niqab. Patrick Snyder, a religious studies professor at the Universite de Sherbrooke, summarized the a priori judgment made by many Quebecers (evidence 
of the first orientation) when he explained that they see religion as inherently oppressive (Un processus historique). Similarly, Rachida Azdouz, associate dean of continuing education at the Université de Montréal, characterized the wearing of a niqab as a "radical" religious practice (Pour une charte de la laïcité).

The women who had worn a niqab also adopted varied orientations toward the rest of Quebec society, in particular women from Quebec who dressed "immodestly." Dayna Ahmed, for instance, adopted the second orientation, claiming to know better than they what motivated their actions. Ahmed described herself as a niqab-wearing feminist and agreed with Western feminists who opposed the hypersexualization of women in advertising and elsewhere. She still insisted, however, that women who wore makeup and paid attention to their appearance did so for men's sake. She hesitated to recognize that they were making a choice, much as she made a choice to wear the niqab (Je suis une féministe musulmane)..$^{13}$

In light of these internal contradictions, how can we assess the Derrière le voile series as an artifact of cultural translation? The stories contributed to the second of Lecomte's declared goals, namely to contribute to an ongoing conversation. What about her first goal, namely to give readers a better understanding of why women in Quebec would choose to wear a niqab? More to the point, did readers' comments in response to the series reflect an orientation of openness toward these women? This is the question I investigate in the next section.

\section{Readers' comments: modes of interactivity}

Past research on readers' comments and news translation has found that the structure of the forum interface has an effect on the level of interaction between readers, and that this level of interaction affects the content of their comments. The pattern holds here, too. One measure of interactivity is the ratio of comments responding to the article (first-order responses) in comparison to comments responding to other comments (second-order responses), with more second-order responses indicating higher levels of interactivity (see Rafaeli and Sudweeks 1997). Predictably, perhaps, forums that made responding to other comments difficult contained more first-order responses, while those that made it easy contained more second-order responses. For example, the New York Times published a series of articles in 2008 about life in Russia, with translated versions published on a Russian-language website. The Englishlanguage comment section displayed twenty-five responses per page and allowed users only to enter text into a text box. Of the responses posted there, 80 percent were first-order, while less than 15 percent were second-order. The Russian-language website, on the other hand, displayed comments in linked threads, and users could respond to other comments simply by pressing the reply button. Of the comments posted there, only about 15 percent were first-order, while 85 percent were secondorder. In other words, the Russian forum was considerably more interactive than the English forum. As a result of this interactivity, comments on the Russian forum were more likely to deviate from the topics addressed by the New York Times: responses to responses frequently addressed something other than the original article (Conway and Vaskivska 2010). 


\subsection{Interactivity and Derrière le voile}

The level of interactivity on the forum of the Derrière le voile series fell between these two examples. Of the 150 comments posted between 19 May and 18 October 2010, ninety-eight (or 65 percent) were first-order, fifty (or 33 percent) were second-order, and two (or 1 percent) had been removed by the moderators. The interface appeared to influence interaction between readers leaving comments, as was the case above. In its default mode, it displayed the five most recent comments at a time in reverse chronological order, so that the most recent comment always showed first. Comments were not organized in threads, meaning that people who wanted to respond directly to other comments had to cut and paste them into a text box. They could, however, click en accord or en désaccord to express agreement or disagreement

Evidence suggests that most readers read a page or two of comments (i.e. the first five or ten comments) and responded to those. Of the forty-six second-order comments where readers quoted another comment directly or identified the screen-name of the person to whom they were responding, the median number of comments between the comment prompting their response and their response itself was 4.5. Although most readers seem to have read the comments in their default display mode, evidence suggests that not everyone did so. A handful of comments from June and August responded to some of the comments made when the series was first posted in May ("marina007," 30 June 2010, 6:37 and "Mado2010," 23 August 2010, 10:02, responding to "bigpike," 19 May 2010, 15:32). ${ }^{14}$ Another reader began by apologizing for responding without having made it through all of the previous comments, even after spending two hours reading them ("RenaudLG," 9 June 2010, 15:18).

\subsection{Readers'opposition to the niqab}

One result of readers' mode of interacting with the forum was that most comments did in fact relate to the topic of the series. In their interactions, readers also frequently expressed opinions about whether women should be allowed to wear a niqab in Quebec. Table 1 describes the number of comments where readers opposed or did not oppose the act of wearing a niqab.

TABLE 1

Readers' stance toward the act of wearing a niqab $(\mathrm{N}=148)$

\begin{tabular}{|l|c|c|c|}
\hline & $\begin{array}{c}\text { Number of } \\
\text { comments }\end{array}$ & $\begin{array}{c}\text { Number of readers expressing } \\
\text { agreement with comment }\end{array}$ & $\begin{array}{c}\text { Number of readers expressing } \\
\text { disagreement with comment }\end{array}$ \\
\hline oppose & 116 & 4669 & 904 \\
\hline not oppose & 14 & 125 & 578 \\
\hline not clear & 18 & 303 & 312 \\
\hline
\end{tabular}

The reasons people gave for opposing the veil included the defense of Quebec's secular society, the need to see people's faces to ensure public safety, and the sentiment that immigrants should adopt the customs of their new home. The reasons people gave for not opposing the veil included respect for Muslim women's capacity to make their own decisions and the defense of inclusive notions of multiculturalism. It is important to note that non-opposition to the veil rarely translated into support. 
A number of responses did not indicate clear opposition or non-opposition to the veil, in most cases because they were second-order comments that no longer related to the series itself. Table 1 also describes the number of times other readers clicked on the en accord or en désaccord buttons accompanying each comment to express agreement or disagreement. ${ }^{15}$ These rates of opposition and non-opposition, as well as the rates of agreement and disagreement, follow the patterns described elsewhere, such as the poll cited above or the witness testimony about Bill 94 before the National Assembly. Readers - both those leaving comments and those clicking en accord or en désaccord - overwhelmingly opposed the niqab.

\subsection{Readers' orientations toward women wearing a niqab}

These patterns raise questions about readers' orientations toward the women described in the series. Did opposition to the niqab correlate with specific orientations? Table 2 suggests that it did: every reader adopting the first or second orientations opposed the niqab.

TABLE 2

Readers' orientations toward Muslim women wearing niqab in Derrière le voile series $(\mathrm{N}=148)$

\begin{tabular}{|l|c|c|c|c|c|}
\hline & $\begin{array}{c}\text { Number of } \\
\text { readers } \\
\text { opposing } \\
\text { wearing niqab }\end{array}$ & $\begin{array}{c}\text { Number of } \\
\text { readers not } \\
\text { opposing } \\
\text { wearing niqab }\end{array}$ & $\begin{array}{c}\text { Number of } \\
\text { readers having } \\
\text { an unclear } \\
\text { stance toward } \\
\text { wearing } \text { niqab }\end{array}$ & $\begin{array}{c}\text { Number of } \\
\text { readers } \\
\text { expressing } \\
\text { agreement with } \\
\text { comment }\end{array}$ & $\begin{array}{c}\text { Number of } \\
\text { readers } \\
\text { expressing } \\
\text { disagreement } \\
\text { with comment }\end{array}$ \\
\hline Orientation 1 & 58 & 0 & 0 & 2546 & 424 \\
\hline Orientation 2 & 24 & 0 & 0 & 979 & 178 \\
\hline $\begin{array}{l}\text { Orientations 1 } \\
\text { and 2 }\end{array}$ & 4 & 0 & 0 & 199 & 49 \\
\hline Orientation 3 & 3 & 14 & 5 & 193 & 773 \\
\hline $\begin{array}{l}\text { Orientation } \\
\text { not clear }\end{array}$ & 27 & 0 & 13 & 1180 & 370 \\
\hline
\end{tabular}

Comments demonstrating the first orientation contained a priori statements about the universality of Western or Québécois values, frequently framing the issue as one of "respect" for the "host" culture. For example, a reader with the screen-name "ginette lavallée" wrote:

(1) C'est un symbole de soumission, point à la ligne. Nous sommes en occident et, en occident, les femmes ne se voilent pas. Ces groupes d'ethnies différentes font le choix de vivre au Québec, alors on respecte comment l'on vit au Québec.

(It's a symbol of submission, end of story. We are in the West, and in the West, women don't wear veils. These different ethnic groups make a choice to live in Quebec, so they should respect how we live in Quebec.)

("ginette lavallée" 1 June 2010, 12:31; translated by the author) $)^{16}$

Comments demonstrating the second orientation expressed what appeared to be an openness to the idea that Muslim women's experiences might differ from the reader's own. At the same time, they also made it clear that the reader thought he or she knew these women better than they knew themselves. For example, a reader called "trebor" responded to Sheeba Shukoor, subject of the story Adopter le niqab, puis le laisser: 
(2) Citation: "J’ai aimé porter le niqab. Je ne le porte plus parce que, je le reconnais, c'est difficile. Mais si ma foi est assez forte, je pourrais le reporter." Mme Sheeba Shukoor

J'interprète la 2ème phrase tel que: Si mon "exaltation" est assez forte, celle qui donne une énergie, une force mentale très grande, quelque chose qui transporte comme sur un nuage et qu'on peut aisément prendre comme étant un lien avec son djeu [sic] alors, je pourrais reporter le niqab.

J'espère que Mme Sheeba Shukoor va en prenant de la maturité, continuer à faire passer la raison, celle qui exige le calme au cerveau [...].

(Citation: "I liked wearing the niqab. I no longer wear it because, I admit, it's hard. But if my faith is strong enough, I could wear it again." Mrs. Sheeba Shukoor I interpret the second sentence as: If my "exaltation" is strong enough, which gives me energy, great mental strength, something that carries me as if I were on a cloud that you might take as being a connection to god, I could wear the niqab again.

I hope that Mrs. Sheeba Shukoor, as she grows in maturity, will come to rely on reason, which requires a calm mind [...].)

(“trebor" 19 May 2010, 20:59; translated by the author)

Comments demonstrating the third orientation expressed a willingness to believe that someone might choose to live her life differently for reasons that were not immediately apparent to the reader, as in the example below, which was directed at "ginette lavallée":

(3) Vous vivez dans un terreau d'accueil. Ça ne fait que 400 quelques années que les français sont ici. La société change depuis. Notre réalité est une mouvance entre perte de ce qu'on est et création de ce que l'on sera. Le vrai Québécois n'existe pas. Même le Québécois moyen n'existe pas. Ici, des gens vivent encore avec la mentalité de l'ère Duplessis. D’autres créent le futur. Entre les deux, le Quebec se cherche à chaque jour.

(You live in fertile, welcoming soil. The French arrived here only 400 years ago. Society has been changing ever since. Our reality is a movement between the loss of what we are and the creation of what we will be. The true Quebecer does not exist. Not even the average Quebecer. Here, some people still live in the Duplessis era [before the Quiet Revolution]. Others create the future. Between the two, Quebec is seeking itself every day.)

(“mononk," 5 June 2010, 10:29; translated by the author)

Some readers expressed ideas indicating both the first and second orientations, while others were not clear in their orientation because they did not discuss the women in the Derrière le voile series, usually because they were responding to other comments.

\subsection{Complexity of readers' orientations}

The patterns described in Table 2 suggest a correlation between the first and second orientations and opposition to the niqab, both for readers leaving comments and for those expressing agreement or disagreement by clicking on en accord or en désaccord. ${ }^{17}$ More interesting, however, are the responses demonstrating the third orientation. The authors of three comments opposed the niqab even as they expressed openness to the idea that women choosing to wear it made that choice freely. One opposed the veil personally but asked whether what was important was not what a 
person wore but what she thought ("Siocnarf," 22 May 2010, 19:12). Another opposed the niqab for reasons related to security but still insisted that if people learn more about Islam, they will come to see that most women are not forced to wear it ("enaivlys," 25 May 2010, 14:26). The third was a woman who had converted to Islam and chose not to wear a veil, insisting however that everyone chooses to dress as they please (“AndyMandy," 28 May 2010, 3:07).

Thus, even if all the comments adopting the first and second orientations opposed the niqab, the comments demonstrating the third orientation reveal a greater complexity. An exchange taking place largely between 23 May and 26 May 2010 between a reader with the screen-name "amel espoir," who identified herself as a Muslim woman who did not wear a niqab, and six other readers illustrates this complexity. In her seven comments, "amel espoir" argued that wearing a hijab or headscarf was commanded by God and made it clear that, as a Muslim herself, she recognized that women choosing to wear a niqab did so freely. It was not clear until her fourth comment that she was personally opposed to the niqab, however. ${ }^{18}$ Other readers, all of them opposed to the niqab, criticized "amel espoir" for her view that God would punish women not wearing a hijab, although they did not necessarily express an opinion about the women in the Derrière le voile series itself. "Amel espoir"'s openness toward Muslim women wearing a niqab did not translate into an openness toward Western countries such as Canada, however. For instance, she wrote in one comment:

(4) par contre moi je vous comprend, il est télement plus facile de n'avoir aucun engagement, de ne suivre aucune loi, de faire ce que l'on veut, et d'etre seulement chretien par le nom, de croire que ${ }^{\star}$ Jesus $^{\star}$ (que le salut et la benediction soient sur lui) a endossé tous vos pechés et que le Paradis vous est garanti!!!! donc libre à vous de gouter aux plasirs de la vie sans limites ni mesure [...] et vous irez tous au Paradis, HITLER en tant que chretien y est deja!!!!!

(On the other hand, I understand you. It's so much easier to not be engaged, to follow no laws, to do what you want, and to be Christian only in name, to believe that ${ }^{*}$ Jesus $^{*}$ (salvation and blessing be upon him) has forgiven all your sins and Heaven is guaranteed for you!!!! So you're free to taste all the pleasures of life without limit or measure [...] and you'll all go to Heaven. HITLER as a Christian is already there!!!!!)

(“amel espoir," 25 May 2010, 15:25; translated by the author)

In this comment, "amel espoir" adopted an orientation of the second type toward her interlocutors: by her account, she knew them better than they knew themselves. Openness toward one group did not translate into openness toward another.

This examination of the comment section for the Derrière le voile series suggests that the series did not help readers - at least those who left comments - overcome the gulf of incomprehension that Anne-Marie Lecomte wanted to address. Readers were not disposed to see the world from a foreign perspective, especially one that had the potential to threaten hard-won secular values or even public safety. However, the articles did encourage a conversation, both in the broad sense (the forum's interactivity) and in the narrow sense (conversations such as "amel espoir"'s), that was more complex than initial patterns would suggest, and in that respect, Lecomte succeeded in the second of her goals. 


\section{Conclusion: cultural translation, interactivity, and the future of public media}

One value of the Derrière le voile series is that it provides insight into a broader set of questions that policy-makers around the world are posing about public media and multiculturalism. As Flew (2011) points out, after nearly three decades of handwringing about the decline of public media (see, for example, Garnham 1983), there is renewed enthusiasm among scholars and policy-makers about their ability to contribute to "a flourishing digital commons" by "providing content across multiple platforms to diverse publics" (Flew 2011: 215). The questions policy-makers are posing relate not only to representing multicultural communities, but also to the relationship between delivery technology, access, and the production of content, as well as to the integration of immigrants who do not share a common set of values, social expectations, or language (see Flew 2011: 216-217).

Series such as Derrière le voile provide examples of how public media can address these questions, but the answers they provide, such as they are, are not definitive. In particular, my analysis here provides only a snapshot of the interactions between a Radio-Canada.ca journalist, the people she wrote about, and the readers who responded to her articles. What is important, however, is the contradiction it revealed between readers' orientation toward groups unlike themselves and their willingness to engage in conversation.

This contradiction has scholarly and practical value and is worth exploring further. What impact would ongoing conversation have on readers' willingness to be open to the Other? The cultural transformation described by Bouchard and Taylor will be more likely to contribute to social cohesion if it is mutual, the result of twoway communication between Quebec's majority and minority groups. How might such communication be encouraged? One of the readers who expressed openness to Muslim women wearing a niqab did so, as she explained, precisely because she had gotten to know two women who wore a niqab ("LaQuébécoise100," 20 May 2010, $4: 12$ ). Would such conversation lead more people - members of both Quebec's majority and minority cultures - to a similar state of openness? On the other hand, three readers left comments about how they were tired of the "elitists" at Radio-Canada trying to force them to see the world from a foreign perspective ("Juhnsodi," 20 May 2010, 6:58; "Réflexion2000," 21 June 2010, 16:30; “LeFrereToc," 26 August 2010, 12:32). To what degree would ongoing conversation strengthen this sentiment? This is where further experiments in interpretive long-form journalism would be worthwhile. Finding ways to cast the Other in a less menacing light is a worthy goal, and this would be one way to pursue it.

\section{NOTES}

1. NATIONAL ASSEMBLY (2010): Bill 94 - An Act to establish guidelines governing accommodation requests within the Administration and certain institutions, introduced by Madam Kathleen WEIL, Minister of Justice. 1st Session, 39th Legislature. Québec: Québec Official Publisher. Visited on 15 September 2012, <http://www.assnat.qc.ca/en/travaux-parlementaires/projets-loi/projetloi-94-39-1.html>.

2. Lecomte, Anne-Marie (28 May 2010): Derrière le voile... des femmes [Women behind the veil]. Radio Canada.ca. Visited in May 2010, <http://www.radio-canada.ca/nouvelles/societe/ 2010/05/17/007-niqab-intro.shtml>. An eighth story was published in October 2010, after I had 
begun analyzing the reader's comments. Because its comment section was distinct from the one for the first seven stories, it does not figure into my analysis.

3. CANADA, DEPARTMENT OF THE SECRETARY OF STATE, CANADIAN CITIZENSHIP BRANCH (1967): The Canadian family tree: Centennial edition 1867-1967. Ottawa: Queen's Printer.

4. Bouchard, Gérard and TAYlor, Charles (2008): Building the future: A time for reconciliation (abridged report). Quebec City: Gouvernement du Québec.

5. See, for instance, Kathleen Weil's interview.

6. ANGUS REID PUBLIC OPINION (27 March 2010): Four-in-Five Canadians Approve of Quebec's Face Veil Legislation. The Poll Archive. Visited on 15 September 2012, <http://www.angus-reid. com/polls/43015/four-in-five-canadians-approve-of-quebecs-face-veil-legislation/>.

7. ASSOCIATION DES RETRAITÉES ET RETRAITÉS DE L'ÉDUCATION ET DES AUTRES SERVICES PUBLICS DU QUÉBEC (AREQ) (2010): Projet de loi 94 - La laïcité de l'État québécois? Le gouvernement Charest n'est ni pour, ni contre, bien au contraire. In: Mémoires déposés lors du mandat «Consultation générale sur le projet de loi n 94». Assemblée nationale du Québec (18 Mai 2010). Visited on 18 February 2011, <http://www.assnat.qc.ca/fr/travaux-parlementaires/commissions/CI/mandats/Mandat-12329/memoires-deposes.html $>$.

8. CONFÉDÉRATION DES SYNDICATS NATIONAUX (2010): La conciliation des droits dans une société laïque. In: Mémoires déposés lors du mandat «Consultation générale sur le projet de loi $n^{\circ} 94$ 》. Assemblée nationale du Québec (18 Mai 2010). Visited on 18 February 2011, <http://www.assnat. qc.ca/fr/travaux-parlementaires/commissions/CI/mandats/Mandat-12329/memoires-deposes.html>.

9. ElSsolh, Bachar, Benyoucef, Brahim et Blili, Ismail (2010): Pour un Québec inclusif et rassembleur: Le projet de loi 94 est préjudiciable envers les Québécois(es) de confession musulmane. In: Mémoires déposés lors du mandat "Consultation générale sur le projet de loi $n^{\circ} 94$ ». Assemblée nationale du Québec (18 Mai 2010). Visited on 18 February 2011, <http://www.assnat.qc.ca/fr/ travaux-parlementaires/commissions/CI/mandats/Mandat-12329/memoires-deposes.html $>$.

10. SIMONE DE BEAUVOIR INSTITUTE (7 April 2010): Simone de Beauvoir Institute's statement in response to Bill 94 . Visited 18 February 2011, <http://wsdb.concordia.ca/documents/SdBI2010Bill94bilingualresponse.pdf $>$. This notion stands in contrast to the one advanced by scholars in the field of postcolonial literature, who treat cultural translation as a form of transposition whereby an element of the foreign is "translated" into the familiar. See Conway (2012a).

11. Openness is a necessary condition, but it is not sufficient. In fact, journalistic norms work against cultural translation in this sense. As has been well documented (e.g. Bassnett 2005), journalists typically adopt an acculturating approach when translating news for readers. To make foreign interpretations of objects or events meaningful to their readers, journalists must recast them so that they make sense within their readers' horizon of expectations, a recasting that has a distorting effect on the interpretations themselves. See Conway and Vaskivska (2010) and Conway (2010).

12. Broadcasting Act (S.C. 1991, c.11) (Last amended on March 16, 2012) Minister of Justice, Canada. "3. (1) It is hereby declared as the broadcasting policy for Canada that [...] $(m)$ the programming provided by the Canadian broadcasting corporation should [...] (viii) reflect the multicultural and multiracial nature of Canadian society. Visited on 15 September 2012, <http://laws-lois.justice. gc.ca/PDF/B-9.01.pdf $>$.

13. As one of the peer reviewers pointed out, Ahmed's orientation in this example draws attention to the bidirectional nature of the interaction between Muslims and Quebecers, and it highlights the ways in which the categories "Muslims" and "Quebecers" overlap. Although I have limited my analysis in this article to readers' responses to a journalist's attempt to "translate" Muslims, it will be important in future research to consider the need for mutual accommodation.

14. The most efficient way to describe comments uniquely is by screen-name, date, and time of posting, the style I adopt here.

15. Tables 1 and 2 reflect the comments as they stood on 21 October 2010.

16. In this and the other quotations, I reproduce comments in their original form, without correction except for minor formatting changes.

17. We should not generalize from these statistics, however, because they are not a representative sample. We cannot verify readers' identity, nor where they are from, and we must take readers at their word about those aspects of their identity they choose to reveal. Single comments also do not necessarily reflect the entire range of a reader's opinion on a topic.

18. Consequently, with the exception of her fourth comment, all her comments were counted as "stance toward niqab not clear" in Tables 1 and 2. 


\section{REFERENCES}

Adams, Michael (2009): Muslims in Canada: Findings from the 2007 Environics survey. Horizons. 10(2):19-26.

AsAd, Talal (1986): The concept of cultural translation in British cultural anthropology. In: Clifford James and George E. Marcus, eds. Writing Culture: The Poetics and Politics of Ethnography. Berkeley: University of California Press, 141-164.

BAssnett, Susan (2005): Bringing the news back home: Strategies of acculturation and foreignisation. Language and Intercultural Communication. 5(2):120-130.

Conway, Kyle (2010): News translation and cultural resistance. Journal of International and Intercultural Communication. 3(3):187-205.

Conway, Kyle (2012a): A conceptual and empirical approach to cultural translation. Translation Studies. 5(3):264-279.

Conway, Kyle (2012b): Quebec's Bill 94: What's "reasonable"? What's "accommodation"? And what's the meaning of the Muslim veil? American Review of Canadian Studies. 42(2):195209.

Conway, Kyle and Vaskivska, Tetiana (2010): Consuming news translation: The New York Times online and the "Kremlin rules" experiment. Across Languages and Cultures. 11(2):233-253.

Diв, Kamal (2006): Now that religious diversity is upon us. Canadian Diversity. 5(2):39-44.

FLEw, Terry (2011): Rethinking public service media and citizenship: Digital strategies for news and current affairs at Australia's Special Broadcasting Service. International Journal of Communication. 5:215-232.

FujII, Akio (1988): News translation in Japan. Meta. 33(1):32-37.

GADAMER, Hans-Georg (1960/2003[1989]): Truth and Method. (Translated by Joel Weinsheimer and Donald G. Marshall) 2nd rev. ed. New York: Continuum.

Gambier, Yves (2006): Transformations in international news. In: Kyle Conway and Susan Bassnett, eds. Translation in Global News. (Proceedings of the conference held at the University of Warwick, Coventry, 23 June 2006) Coventry: University of Warwick Centre for Translation and Comparative Cultural Studies, 9-21.

Garnham, Nicholas (1983): Public service versus the market. Screen. 24(1):6-27.

JordAn, Shirley Ann (2002): Ethnographic encounters: The processes of cultural translation. Language and Intercultural Communication. 2(2):96-110.

KalbaCH, Warren E. (1970): The Impact of Immigration on Canada's Population. Ottawa: Dominion Bureau of Statistics.

McAndrew, Marie (2010): The Muslim community and education in Quebec: Controversies and mutual adaptation. Journal of International Migration and Integration. 11(1):41-58.

Рyм, Anthony (2004): The Moving Text: Localization, Translation, and Distribution. Philadelphia: John Benjamins.

Rafaeli, Sheizaf and Sudweeks, Fay (1997): Networked interactivity. Journal of ComputerMediated Communication. 4(2). Visited 18 February 2011, <jcmc.indiana.edu/vol2/issue4/ rafaeli.sudweeks.html>.

SAID, Edward W. (1997): Covering Islam: How the Media and the Experts Determine How We See the Rest of the World. Rev. ed. New York: Vintage.

Sorby, Stella (2006): Translating news from English to Chinese: Complimentary and derogatory language usage. In: Kyle Conway and Susan Bassnett, eds. Translation in Global News. (Proceedings of the conference held at the University of Warwick, Coventry, 23 June 2006) Coventry: University of Warwick Centre for Translation and Comparative Cultural Studies, 113-126.

TAYlor, Charles (1994): The politics of recognition. In: Amy Gutmann, ed. Multiculturalism: Examining the Politics of Recognition. Princeton, NJ: Princeton University Press, 25-73.

van Doorslaer, Luc (2010): The double extension of translation in the journalistic field. Across Languages and Cultures. 11(2):175-188. 
1012 MeTA, LVII, 4, 2012

\section{INTERVIEW}

WeIL, Kathleen (12 April 2010): Bill Seeks To Ban Muslim Veil In Quebec. Interviewed by Michele Norris, All Things Considered, National Public Radio. Visited on 15 September 2012, $<$ http://www.npr.org/templates/story/story.php?storyld=125866591>. 